\title{
ISOLASI GLUKOSAMIN DARI EKSOSKELETON KECOA MADAGASKAR (Gromphadorhina portentosa)
}

\author{
${ }^{1}$ Fairuz Rifdah Permanasari, ${ }^{2}$ Indra Topik Maulana, ${ }^{3}$ Livia Syafnir \\ 1,2,3 Prodi Farmasi, Fakultas Matematika dan Ilmu Pengetahuan Alam, Universitas Islam Bandung, \\ Jl. Ranggagading No. 08 Bandung 40116

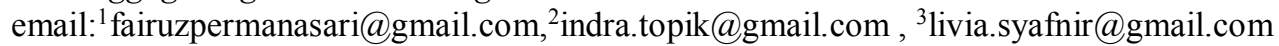

\begin{abstract}
ABSTRAK
Kecoa Madagaskar (Gromphadorhina portentosa) merupakan salah satu jenis kecoa yang banyak dimanfaatkan sebagai pakan burung,ikan arwana, tarantula dll. Kecoa ini berukuran lebih besar, tidak memiliki sayap, tidak berbau, jinak, dan bergerak lambat. Eksoskeleton kecoa Madagaskar mengandung senyawa kitin yang berpotensi untuk dijadikan sumber glukosamin yang bermanfaat dalam produksi cairan synovial serta mencegah destruksi tulang. Tujuan penelitian ini adalah menghasilkan glukosamin dari eksoskeleton kecoa Madagaskar. Glukosamin diperoleh melalui proses deproteinasi, demineralisasi, deasetilasi yang kemudian dilanjutkan dengan proses hidrolisis kimiawi dengan $\mathrm{HCl} 32 \%$. Penelitian ini memberikan hasil rendemen glukosamin yang dihasilkan adalah sebesar 22,16\% dengan nilai LoD 0,917\%. Spektrum FTIR menunjukkan adanya pita serapan pada daerah $\mathrm{NH}, \mathrm{OH}, \mathrm{C}-\mathrm{N}, \mathrm{C}-\mathrm{H}, \mathrm{C}-\mathrm{O}$, gugus Amina Sekunder, dan Glikosida
\end{abstract}

Kata Kunci: Kecoa Madagaskar,kitin, kitosan, glukosamin

\begin{abstract}
Gromphadorhina portentosa is one type of cockroach that often used widely as feed for bird, arwana, tarantula, and etc. This cockroach has a size larger than other, has no wing, no smell, tame, and move slow. This cockroach Exoskeleton contains chitin substance which potential as glucosamine resource which have benefit in synovial production process to protect bone from destruction. The aim of this research was to produce glucosamine from exosceleton of Gromphadorhina portentosa. Glucosamine was resulted by deacetylation process with $\mathrm{NaOH}$ $50 \%$ and followed by chemical hydrolysis with $\mathrm{HCl} 32 \%$. The yield of glucosamine was about $22,16 \%$ with level of solubility was about $95,35 \%$ And Lost of Drying was $0,917 \%$.
\end{abstract}

Keywords: Cockroach Madagascar, chitin, chitosan, glucosamine hydrochloride

\section{PENDAHULUAN}

Kecoa merupakan serangga hama yang kehidupannya sangat dekat dengan aktivitas manusia. Kecoa Madagaskar (Gromphadorhina portentosa) merupakan salah satu jenis kecoa yang banyak dimanfaatkan sebagai pakan burung, ikan arwana, tarantula dll. Pada umunya kecoa
Madagaskar berbeda dengan kecoa yang berada di lingkungan sekitar. Kecoa ini berukuran lebih besar, tidak memiliki sayap, tidak berbau, jinak, geraknya lambat dan tidak menggigit. Kecoa Madagaskar ini berasal dari Madagaskar, sebuah pulau yang berada di sebelah tenggara benua Afrika (Selvana,2014).

Kecoa Madagaskar memiliki 
Isolasi Glukosamin Dari Eksoskeleton Kecoa Madagaskar..

eksoskeleton yang nantinya akan mengelupas seiring dengan bertambahnya ukuran tubuh kecoa (pengelupasan/molting). Selama ini kecoa dianggap binatang yang menjijikan dan dapat menyebabkan penyakit. Kecoa Madagaskar diketahui memiliki karakteristik yang berbeda dibandingkan kecoa lainnya. Kecoa ini diketahui memiliki manfaat sebagai sumber kitin yang merupakan bahan dasar glukosamin. Menurut Muzzarelli,(1985:435) eksoskeleton kecoa dilaporkan mengandung senyawa kitin dengan rendemen $35 \%$.

Kitin merupakan polisakarida struktural yang digunakan untuk menyusun eksoskleton dari klasifikasi artropoda. Kitin dapat mengalami degradasi secara biologis sehingga penggunaan kitin menjadi terbatas. Oleh karena itu, kitin perlu diubah menjadi kitosan agar dapat digunakan secara lebih luas. Kitosan merupakan polisakarida alami yang tidak beracun, biodegradable, dan biocompatible yang dihasilkan dari proses deasetilasi kitin yang terkandung di dalam eksoskeleton artopoda (Sugita,2009:25).

Kitosan diketahui tersusun atas monomer glukosamin yang telah dimanfaatkan sebagai suplemen makanan untuk mencegah dan menangani penyakit osteoratritis. Glukosamin telah terbukti dalam banyak percobaan sainstifik untuk merawat kesakitan osteoartritis, memulihkan rawan, memperbaharui saluran dan memperbaiki sendi-sendi yang rusak akibat osteoartritis. Menurut WHO (2004) Prevalensi penderita osteoartritis di dunia tahun 2004 mencapai 151,4 juta jiwa dan 27,4 juta jiwa berada di Asia Tenggara.

Seiring dengan semakin meningkatnya kebutuhan akan glukosamin, maka diperlukan suatu upaya untuk menyediakan glukosamin dalam jumlah besar dengan kualitas yang baik dan harganya pun dapat dijangkau oleh kalangan masyarakat untuk mendapatkan suplemen glukosamin. Berdasarkan paparan sebelumnya, eksoskeleton memiliki potensi untuk dikembangkan sebagai salah satu sumber glukosamin. Berdasarkan paparan diatas, maka perumusan masalah dalam penelitian ini yaitu apakah eksoskeleton kecoa Madagaskar dapat digunakan sebagai sumber glukosamin.

Penelitian ini bertujuan untuk menghasilkan glukosamin dari kecoa Madagaskar menggunakan metode hidrolisis kimiawi dengan konsentrasi $\mathrm{HCl} 32 \%$. Manfaat dari penelitian yang dilakukan yaitu dapat memberikan informasi kepada peneliti tentang kitin yang berasal dari eksoskeleton kecoa Madagaskar mengandung glukosamin dan dapat diteruskan oleh peneliti lain untuk melihat aktivitas glukosamin pada penyakit osteoartritis. 


\section{METODE PENELITIAN}

Penelitian dilakukan di Laboratorium Riset program studi Farmasi, FMIPA Universitas Islam Bandung. Penelitian ini dilakukan melalui beberapa tahap, meliputi determinasi hewan, penyiapan bahan, karakterisasi parameter standar, ekstraksi kitin, transformasi kitin menjadi kitosan dan hidrolisis kimiawi glukosamin.

Bahan yang digunakan adalah eksoskeleton kecoa Madagaskar yang diperoleh dari daerah Cipondoh Tanggerang. Penyiapan bahan meliputi perajangan eksoskeleton selanjutnya dikeringkan pada lemari pengering dengan suhu $40-50^{\circ} \mathrm{C}$. Bahan selanjutnya dideproteinasi dan demineralisasi hingga diperoleh kitin yang telah murni dari protein dan mineral. Kitin murni kemudian dideasetilasi dengan larutan $\mathrm{NaOH} 50 \%$ hingga diperoleh residu kitosan. Kitosan selanjutnya dihidrolisis dengan menggunakan $\mathrm{HCl} 32 \%$ hingga dihasilkan Glukosamin hidroklorida. Glukosamin yang diperoleh selanjutnya meliputi : warna dan tekstur, rendemen, kelarutan, susut pengeringan, kadar abu total dan tidak larut asam, kadar air. Struktur glukosamin dianalisis menggunakan Fourier Transform InfraRed (FTIR).

\section{HASIL DAN PEMBAHASAN}

Proses pengolahan bahan menghasilkan rendemen bahan kering eksoskeleton siap olah sebesar $20 \%$ atau 200 gram dari $1 \mathrm{~kg}$ bahan. Secara organoleptis, eksoskeleton kecoa madagaskar diketahui berwarna coklat gelap disertai dengan permukaannya yang licin dan keras. Kulit eksoskeleton juga diketahui berbentuk oval dan memiliki panjang sekitar 6 $\mathrm{cm}$. Deskripsi tersebut memperlihatkan bahwa bahan baku telah memenuhi standar yang ditetapkan seperti yang tertera pada selvana, 2014. Adapun karakteristik bahan secara lengkap ditunjukkan pada tabel 1 .

Tabel 1. Karakteristik Simplisia Eksoskeleton Kecoa Madagaskar

\begin{tabular}{cc}
\hline Parameter & Nilai Kitosan \\
\hline Kadar Abu Total & $3,28 \%$ \\
Kadar Abu tidak Larut Asam & $1,19 \%$ \\
Kadar Air & $5,18 \%$ \\
Kadar Sari Larut Air & $11,22 \%$ \\
Kadar Sari Larut Etanol & $3,81 \%$ \\
\hline
\end{tabular}

Karakteristik kadar abu memperlihatkan didalam bahan adalah sebesar 3,28\% dimana bahwa kandungan senyawa logam anorganik sebesar $1,19 \%$ berasal dari cemaran senyawa 
Isolasi Glukosamin Dari Eksoskeleton Kecoa Madagaskar..

anorganik dari luar bahan. Hal ini sangatlah wajar, mengingat eksoskeleton selain dibangun oleh struktur fosfolipid juga terdapat kandungan mineral anorganik seperti kalsium dalam jumlah yang cukup tinggi yang akan tertinggal ketika dipijarkan pada saat penetapan kadar abu. Selain kandungan abu, bahan juga diketahui mengandung hanya 5,18\% air jauh dibawah batas maksimal yang diperbolehkan yaitu $10 \%$. Hal ini menjamin bahwa bahan relative lebih aman terhadap adanya cemaran mikroba dan jamur.

Bahan juga diketahui mengandung senyawa kimia yang diketahui bersifat polar (larut dalam air) yaitu sebesar 11,22\% dan senyawa kimia yang bersifat kurang polar (larut dalam etanol) sebesar 3,812\%. Hal ini juga dianggap wajar mengingat eksoskeleton hewan lebih banyak tersusun oleh senyawa polar seperti protein dan lebih sedikit mengandung senyawa non polar karena hanya sedikit jalur metabolisme pembentukan senyawa metabolit sekunder yang bersifat kurang polar.

Proses deproteinasi, demineralisasi, deasetilasi dan hidrolisis menghasilkan bahan (diduga glukosamin hidroklorida) yang memiliki tekstur berbentuk serbuk dengan warna coklat kehitaman, dan tidak berbau. Data lengkap terkait karakteristik kitosan yang dihasilkan dapat dilihat pada tabel 2 .

Tabel 2. Karakteristik Glukosamin Hidroklorida yang Dihasilkan

\begin{tabular}{cc}
\hline Parameter & Nilai Kitosan \\
\hline Tekstur & Serbuk \\
Bau & Tidak berbau \\
Rendemen & $22,16 \%$ \\
Warna & Coklat \\
Derajat Keasaman & 3,2 \\
Loss on Drying (LoD) & $0,9177 \%$ \\
Titik Leleh & $189-195^{\circ} \mathrm{C}$ \\
Uji Dragendorf & Endapan Jingga \\
\hline
\end{tabular}

Serbuk yang dihasilkan (diduga memiliki warna putih, dan cenderung bening glukosamin) memiliki rendemen $22,16 \%$ dari saat dilarutkan dalam air. Derajat keasaman total bahan kering yang digunakan. Serbuk $(\mathrm{pH})$ serbuk yang dihasilkan saat dilarutkan tersebut berwarna putih kecoklatan disebabkan dalam air masih memenuhi standar karena pengaruh pigmen eksoskeleton dan internasional yaitu pada kisaran $\mathrm{pH}$ antara 3 protein pengotor (Sutjijah et al, 2014). 5 (FDA, 2004; EFSA, 2010).

Berdasarkan standar internasional, glukosamin 
Serbuk glukosamin yang dihasilkan juga memiliki parameter LoD yang masih memenuhi standar yaitu dibawah $1 \%$ (USP, 2006). Hal ini menunjukkan bahwa kandungan senyawa yang mudah menguap termasuk air masih cukup rendah dibawah $1 \%$. Serbuk glukosamin yang dihasilkan masih diindikasikan belum murni sempurna, dikarenakan memiliki rentang titik leleh $6{ }^{\circ} \mathrm{C}$ lebih tinggi dari standar yang diperbolehkan yaitu $4{ }^{\circ} \mathrm{C}\left(190-194{ }^{\circ} \mathrm{C}\right)$. Hal ini kemungkinan disebabkan karena masih adanya pigmen warna yang tercampur dengan serbuk glukosamin.
Glukosamin diketahui memiliki gugus amina $\left(\mathrm{R}-\mathrm{NH}_{2}\right)$. Gugus amina tersebut dapat dideteksi dengan menggunakan pereaksi Dragendorf $\left[\mathrm{Bi}\left(\mathrm{NO}_{3}\right)_{3}\right.$ dalam $\mathrm{HNO}_{3}$ dan $\left.\mathrm{KI}\right]$ dan menghasilkan endapan warna jingga hingga kuning seperti halnya pada pengujian golongan alkaloid. Berdasarkan tampilan warna chitosan yang dihasilkan, produk yang diperoleh masih berwarna coklat kehitaman. Hal ini dikarenakan didalam produk masih terdapat pigmen eksoskeleton kecoa yang perlu dilakukan tahapan pemurnian lebih lanjut.

Analisis FTIR terhadap produk glukosamin yang dihasilkan dapat dilihat pada gambar 1.

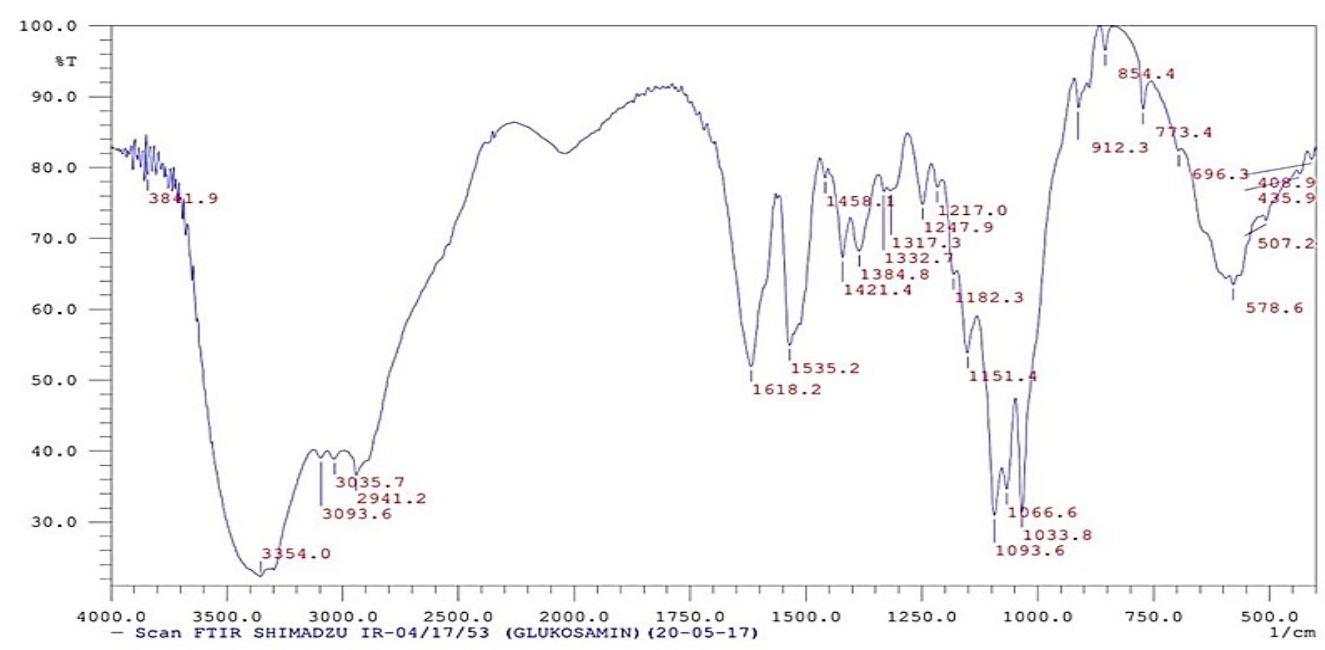

Gambar 1. Spektrum FTIR glukosamin hidroklorida 32\%

Pada spektrum FTIR terlihat adanya gugus samping yang ada pada struktur serapan pada bilangan gelombang $3354 \mathrm{~cm}^{-1}$ glukosamin (kitosan). Spektrum tersebut yang menandakan adanya gugus amin ataupun menunjukkan kemiripan dengan hasil penelitian gugus OH. Kedua gugus tersebut merupakan Mojarrad et al. (2007) dan Silverstein et al. 
Isolasi Glukosamin Dari Eksoskeleton Kecoa Madagaskar..

(2005) yaitu adanya pita serapan pada 3350$3380 \mathrm{~cm}^{-1}$.

Pita serapan gugus $\mathrm{C}-\mathrm{N}$ juga muncul yang ditandai dengan adanya puncak pada kisaran $1093 \mathrm{~cm}^{-1}$. Selain itu, adanya pita serapan pada puncak $1151 \mathrm{~cm}^{-1}$ menunjukkan adanya ikatan glikosidik yang merupakan gugus khas dari suatu glukosamin. Pita serapan gugus N-H amin sekunder juga muncul dengan adanya pita serapan pada $1535 \mathrm{~cm}^{-1}$. Berikut merupakan hasil pengukuran gugus fungsi glukosamin hidroklorida yang disajikan pada Tabel 3.

Tabel 3. Hasil pengukuran gugus fungsi glukosamin hodroklorida

\begin{tabular}{ccc}
\hline \multirow{2}{*}{ Daerah Serapan } & \multicolumn{2}{c}{ Bilangan Gelombang Puncak Serapan cm-1 } \\
\cline { 2 - 3 } & Data analisis & Pustaka \\
\hline O-H & 3354 & $3100-3650^{*}$ \\
C-N & 1384 & $1334-1384 * *$ \\
N-H & 3354 & $3350-3380^{* *}$ \\
Glikosida & 1151 & $1085-1150 * *$ \\
C-H & 2941 & $2800-3300 * * *$ \\
C-O & 1247 & $1050-1260 * * *$ \\
Amina Sekunder & 1535 & $1535-1583 * * * *$ \\
\hline Sumber : *Agusnar (2007); ** Siverstein et al (2005); ***Fessenden,1982;****Mojarrad et al (2007).
\end{tabular}

Glukosamin yang dihasilkan terlihat masih belum murni, sehingga ada potensi spektum FTIR yang dihasilkan juga terinterferensi dengan adanya gugus - gugus pengganggu. Oleh karena itu, perlu kiranya kedepan dilakukan tahapan pemurnian untuk menghilangkan pigmen warna dari glukosamin, sehingga dihasilkan glukosamin yang memenuhi spesifikasi warna yang diharuskan.

Faktor lain yang mempengaruhi perbedaan nilai serapan FTIR adalah perbedaan warna serbuk pada glukosamin, perbedaan konsentrasi asam, bahan pengotor yang tersisa, perbedaan cara hidrolisis, serta waktu selama proses hidrolisis. Perbedaan serapan gelombang setiap gugus fungsi dianggap normal menurut Suptijah et al (2014), apabila bilangan gelombang gugus fungsi masih sesuai dengan standar.

\section{KESIMPULAN DAN SARAN}

\subsection{Kesimpulan}

Penelitian telah berhasil menghasilkan serbuk yang diduga kuat glukosamin Hidroklorida, dengan warna coklat, derajat keasaman 3,2, LoD sebesar 0,9177\% dan titik leleh 189 - $195{ }^{\circ} \mathrm{C}$. rendemen serbuk glukosamin yang dihasilkan adalah 22,16\%. Analisis pembuktian gugus pada glukosamin adalah dengan adanya pita serapan pada spectrum FTIR pada daerah serapan $\mathrm{NH}, \mathrm{OH}, \mathrm{C}$ N, C-H, C-O, gugus Amina Sekunder, dan Glikosida.

\subsection{Saran}


Perlu dilakukan pemurnian lebih lanjut terhadap glukosamin hidroklorida dari pigmen warna eksoskeleton dan protein - protein pengganggu sehingga dapat dihasilkan glukosamin hidroklorida yang berwarna putih.

\section{DAFTAR PUSTAKA}

Agusnar H., 2007. Penggunaan kitosan dari tulang rawan cumi-cumi (Loligo pealli) untuk menurunkan kadar ion logam $\mathrm{Cd}$ dengan spektrofotometri serapan atom. Jurnal Sains Kimia. 11(1):15-20.

European Food Safety Authority [EFSA]., 2009. Scientific Opinion on the substantiation of a health claim related to glucosamine hydrochloride and reduced rate of cartilage degeneration and reduced risk of development of osteoarthritis pursuant, European Food Safety Authority, 7(10):1-9.

Food and Drug Administration [FDA]., 2004. Letter Regarding the Relationship Between the Consumption of Crystalline Glucosamine Sulfate and a Reduced Risk of Osteoarthritis. Docket., P-0060.

Fessenden. R.J \& Fessenden. J.S., 1982. Kimia
Organik. Edisi ketiga Jilid 1. Erlangga, Jakarta.

Mojarrad J.S, Mahboob N, Valizadeh H, Ansarin M, Bourbour S., 2007. Preparation of glucosamine from exoskeleton of shrimp and predicting production by response surface metodhology, Journal of Agricultural and Chemistry. 55:2246-2250.

Muzzarelli, R.A.A., 1985. Chitin in the Polysaccharides. Aspinall. 3(147)

Selvana, Ahadi., 2014. Beternak Kecoa Madagaskar, Dapur Buku, Jakarta.

Silverstein. RM, Webster. FX, Kiemle DJ., 2005. Spectrometric Identification of Organis Compounds. $7^{\text {th }}$ Ed, Willey, United States.

Suptijah P, Bustami I, Ernawati., 2014. Pemanfaatan limbah krustasea dalam pembuatan glukosamin hidroklorida (GlcN $\mathrm{HCl})$ dengan metode autoklaf, Jurnal Teknologi Perikanan dan Kelautan. 5(2): 171-179.

Sugita, Purwantiningsih., Tuti W., Ahmad S., dan Dwi W., 2009. Kitosan Sumber Biomaterial Masa Depan, Kampus IPB Taman Kencana Bogor, Bogor.

World Health Organization., 2004. Global Burden Of Disease, Direktorat World Health Organization 